\title{
Review \\ The Pros and Cons of Rye Chromatin Introgression into Wheat Genome
}

\author{
Kinga Moskal, Sylwia Kowalik, Wiesław Podyma, Bogusław Łapiński and Maja Boczkowska *D \\ National Centre for Plant Genetic Resources, Plant Breeding and Acclimatization Institute-NRI, \\ 05-870 Błonie, Poland; k.smolinska@ihar.edu.pl (K.M.); s.kowalik@ihar.edu.pl (S.K.); \\ w.podyma@ihar.edu.pl (W.P.); b.lapinski@ihar.edu.pl (B.Ł.) \\ * Correspondence: m.boczkowska@ihar.edu.pl
}

check for updates

Citation: Moskal, K.; Kowalik, S.; Podyma, W.; Łapiński, B.;

Boczkowska, M. The Pros and Cons of Rye Chromatin Introgression into Wheat Genome. Agronomy 2021, 11, 456. https://doi.org/10.3390/ agronomy 11030456

Academic Editors: Ioannis N. Xynias, Athanasios G. Mavromatis and Ioannis Mylonas

Received: 31 January 2021

Accepted: 25 February 2021

Published: 1 March 2021

Publisher's Note: MDPI stays neutral with regard to jurisdictional claims in published maps and institutional affiliations.

Copyright: (c) 2021 by the authors. Licensee MDPI, Basel, Switzerland. This article is an open access article distributed under the terms and conditions of the Creative Commons Attribution (CC BY) license (https:// creativecommons.org/licenses/by/ $4.0 /)$.

\begin{abstract}
Rye is one of the most commonly used sources of elite genes in wheat improvement programs. Due to the high collinearity of the genomes of both cereal species, it is possible to obtain interspecific chromosomal translocations and substitution lines. Rye chromatin is used to transfer numerous genes for resistance to biotic and abiotic stresses into the wheat genome. Introgression has also resulted in improved agronomic traits. However, despite the numerous advantages, the transfer of large fragments or whole chromosomes has been quite often accompanied by a decrease in end-use quality. This paper presents an overview of the benefits and drawbacks of using rye as a source of variability in wheat breeding.
\end{abstract}

Keywords: abiotic; agronomic; disease; end-use; introgression; pest; rye; translocation; wheat

\section{Introduction}

Wheat is cultivated from the equator to the Arctic Circle, from sea level to a height of $4500 \mathrm{~m}$ above the sea level in Tibet [1]. However, the best conditions for its cultivation are found in the latitudes $30-60^{\circ} \mathrm{N}$ and $27-40^{\circ} \mathrm{S}$ [2]. The observed increase in wheat production and yield over the last 70 years is a direct result of the Green Revolution. However, just as it has contributed to a significant improvement in productivity, it has led to a significant genetic erosion and loss of diversity [3]. To expand the gene pool, multiple wild and cultivated related species from Triticeae have been used in breeding programs.

In this review, we will summarise information concerning the use of rye as a source of diversity and traits essential for further progress in wheat breeding. We will discuss how fragments of the rye genome contribute to improving the resistance of wheat to biotic and abiotic stresses and how they affect the agronomic traits and end-use value. We hope that this review will help both breeders and researchers around the world, and it will indirectly contribute to improving rye genetic resource characterisation as a source of new genes/alleles for wheat breeding programmes.

\section{Wheat Genome Evolution and Gene Pools}

Common wheat (Triticum aestivum L.) has a complex genome comprising three related genomes that are derived from three different diploid species. It is therefore an allohexaploid (allo, from Greek, means "different") with 2n $=6 x=42$ (AABBDD) [4]. It is considered certain that common wheat was formed as a result of two hybridisation events between Triticum urartu Thumanjan ex Gandilyan $(2 \mathrm{n}=2 \mathrm{x}=14$, AuAu) and an Aegilops speltoides-related species $(2 \mathrm{n}=2 \mathrm{x}=14, \mathrm{BB})$ that occurred 0.5 million years ago, forming Triticum turgidum ssp. diccocoides Korn. ex Asch. \& Graebn., and then 10,000 years ago between tetraploid T. turgidum ssp. diccocoides $(2 \mathrm{n}=4 \mathrm{x}=28, \mathrm{AABB})$ and diploid Aegilops tauschii ssp. strangulata (Eig) Tzvel. ( $\mathrm{n}=2 \mathrm{x}=14$, DD) [5-7]. 
According to the genetic similarities, 21 pairs (seven pairs in each genome) of wheat chromosomes are divided into the seven homoeologous groups, each containing a pair of chromosomes from the A, B and D genomes [8]. Homoeologous chromosomes retain a high degree of DNA sequence homology and gene synteny but differ in numerous functional gene complexes in numerous noncoding and highly repetitive DNA sequences $[7,9,10]$. Nevertheless, wheat behaves like a diploid and homoeologous chromosomes do not pair with each other during meiosis [11-13]. The restriction of homoeologues paring is related to the genetic control of pairing and physical divergence [4,14].

Following the concept of gene pools proposed by Harlan and de Wet and further developed by Jiang et al., the three gene pools, i.e., primary, secondary and tertiary, are related to common wheat $[15,16]$. Species belonging to each of them are used in breeding programs. Within the primary common wheat gene pool are wheat primitive domesticated forms, landraces and the closely related wild species, including tetraploid Triticum dicoccoides Körn. ex Asch. \& Graebn. and the tetraploid A and D genome donors, which carry homologues and hybridise directly with cultivated wheat [1,17]. The secondary gene pool consists of the remaining species polyploid species of the genus Triticum and Aegilops that have at least one homologous genome in common with wheat [17]. More distant diploid and polyploid species from the tribe Triticeae with nonhomologous genomes are classified as the tertiary gene pool of wheat [1,17].

\section{Rye General Description}

Rye (Secale cereale L.) is a diploid species $(2 n=2 x=14, R R)$ belonging to the family Poaceae, subfamily Pooideae, tribe Triticeae. It is a small grain cereal species with a high resistance to biotic and abiotic stresses. Therefore, it can be grown under challenging conditions for other cereal crops. Rye can be grown in infertile, sandy, acidic or saline soils, with the exception of highly saline ones, and, also, on poorly prepared fields. Compared to other small grain cereals, rye is attacked by fewer pathogens, and such infections cause substantially lower yield loss. Rye is also more tolerant to drought than other small-grain cereals, due to its well-developed root system [18].

\section{Rye Chromosomes as a Source of Desirable Genes and Alleles for Wheat}

The use of elite genes from distantly related species is possible through a distant hybridisation approach. Rye, included in the tertiary gene pool of wheat, is one of the most widely used alien sources of diversity and resistance in wheat breeding. The methods for transferring rye chromatin into the wheat genome are not new and have been extensively described in many previous works [14,16,19-22]. Generally, the first step is to obtain addition or substitution lines, which are then used to generate translocation lines that are used in breeding [19]. A sequence analysis of the wheat and rye genomes revealed highly conserved collinearity of their genomes, which should considerably facilitate introgression [23]. However, exchanges of chromosome fragments between heterologous chromosomes occurred during evolution in both wheat and rye, resulting in significant differences in the collinearity of most rye chromosomes compared to their wheat homoeologues. Only chromosome $1 R$ is completely syntenic; chromosomes $2 R, 3 R, 5 R$ and $6 R$ show a relatively high degree of homoeology with chromosome groups 2, 3, 5 and 6 of wheat and contain large syntenic blocks. In contrast, chromosome $4 \mathrm{R}$ shows only partial homology to wheat group 4, while it shows a significant similarity to wheat chromosome group 7 and, partially, to group 6. Chromosome 7R shows low collinearity with wheat chromosomes [23]. Looking at individual chromosome arms, previous results have already indicated that the highest collinearity occurs within 1RS, 1RL, 2RL, 3RS, 4RS, 5RS and 6RS with their homoeologues in wheat $[24,25]$. Translocations occur in the other chromosome arms, which greatly hinders chromosome pairing and recombination. As a result, obtaining wheat-rye recombinant chromosomes is significantly impaired [26,27]. 


\subsection{Chromosome $1 R$}

Chromosome 1R and, in particular, its short arm 1RS have been extensively used in bread wheat improvement programs worldwide [28].

\subsubsection{Introgression Types}

In particular, the 1RS.1BL translocation of whole-chromosome arms is the most commonly utilised source of alien rye chromatin in wheat breeding programs [29]. The karyotype of wheat with the 1RS.1BL translocation contains a chromosome pair in which the short arm of wheat chromosome $1 \mathrm{~B}$ was replaced by a centric break-fusion event with the short arm of chromosome 1R. [30]. It is assumed that there are several independent sources of translocation [31]. The most popular sources of 1RS in wheat cultivars were German 1R(1B) substitution lines of the "Salzmünder Bartweizen" and "Zorba" wheats derived from wheat-rye crosses in the 1920s-1930s by G. Riebesel and G. Kattermann. In both cases, the German cv. "Petkus" was used as the rye component. The Russian cultivars "Aurora" and "Kavkaz" are among the other most common sources of 1RS.1BL translocation, but both also trace their origins back to the cultivar "Petkus" [32,33]. Therefore, there is a significant problem with the lack of genetic differentiation of this genome fragment. The same translocation was introduced into tetraploid wheat lines by crossing common wheat 1RS.1BL and durum wheat [34]. Another source of this translocation is Japanese wheat cv. "Salmon". It was obtained in the 1970s and was derived from octoploid triticale [35]. The use of this cultivar in breeding has been reported only once and resulted in the line KS 80-H-420022, developed by Kansas State University (Manhattan, KS, USA) [36]. Since 2000, new lines with the 1RS.1BL translocation have appeared, using other rye cultivars such as "Paldanghomil", "Aigan", "Baili", "Weiling" and "Weining" as 1RS donors [28,37-39]. To date, more than a thousand lines and cultivars containing 1RS.1BL translocation have been developed worldwide [40].

1RS.1AL translocation has also been used in wheat breeding programs, although on a much smaller scale than that discussed above. To date, about 100 cultivars and lines containing this translocation have been identified [40]. It was first described in the cv. "Amigo", developed in the late 1970s in the USA. The 1RS from the Argentinian "Insave" rye cultivar was introduced via the octoploid triticale cv. "Gaucho" [41,42]. The "Amigo" cultivar was mainly used in American breeding programs [40]. The second source of 1RS.1AL translocation was the line GRS1201 obtained in 1990s in the USA [43]. Its pedigree also traced back to the rye cv. "Insave" (short wheat selection/ "Scout"(TX69A345-2)/ / Insave F.A.") [43]. There are also several sources of 1RS other than "Insave", such as those derived from the original "Petkus" rye, transferred via triticale cv. "Rhino" and "Presto". Early substitutions also included the wheat line E12165 1R from the International Maize and Wheat Improvement Center (CIMMYT) and wheat cv. "Veery" [44,45]. However, they did not attract much interest from breeders.

1RS.1DL translocation is the least used in breeding programs [40]. It was obtained in the 1970s in Australia and contains 1RS from the rye cv. "Imperial".

The substitution lines $1 \mathrm{R}(1 \mathrm{~A}), 1 \mathrm{R}(1 \mathrm{~B})$ and $1 \mathrm{R}(\mathrm{D})$, containing whole $1 \mathrm{R}$ chromosomes, were also created; however, they are mainly used as research material or in the creation of translocation lines, and only a few cultivars contain the substitution $1 \mathrm{R}(1 \mathrm{~B})$.

\subsubsection{Resistance to Biotic Factors}

The 1RS segment contains numerous race-specific disease-resistance genes. The translocation most commonly used in wheat breeding, 1RS.1BL with 1RS derived from the cv. "Petkus", carries the Pm8 gene for resistance to powdery mildew (Blumeria graminis (DC) E.O. Speer f. sp. tritici Em. Marchal) [33]. The phenotypic effect of this gene is sometimes suppressed by its wheat orthologue Pm3, which is present in some wheat genetic backgrounds [46]. In addition, this 1RS fragment also carries the Lr26, Sr31 and Yr9 genes for resistance to brown rust (Puccinia recondita Roberge ex Desm. f. sp. tritici), stem rust (Puccinia graminis f. sp. tritici Eriksson \& Henning) and yellow rust (Puccinia striiformis 
Westend. f. sp. tritici Eriks.), respectively. However, the resistance determined by these genes has already been overcome by new virulent biotypes of the respective pathogens [47]. Of particular concern is the breakthrough of $S r 31$ gene resistance by the Ug99 stem rust race group [48]. This race, identified in East Africa, threatens a major part of the global wheat production [49]. Further works and the use of alternative 1RS sources have enabled the transfer of other resistance genes into wheat, such as $P m C n 17$ (powdery mildew), $Y_{r C n 17,} Y_{r R 212}$ and $y r C H 45-1 b$ (yellow rust) [50,51]. The 1RS.BL also carries the gene $D n 7$, providing broad-spectrum resistance to several biotypes of the Russian wheat aphid (Diuraphis noxia Kurdjumov), which is an economically important pest of wheat [52].

On the other hand, due to the use of different 1RS sources, the 1RS.1AL translocation enriched the wheat gene pool with the Pm17 gene, which is allelic to Pm8 and determines the resistance to powdery mildew, and Sr1RS ${ }^{A m i g o}$, which provides a resistance to stem rust $[42,53]$. In addition to carrying genes providing a resistance to fungal pathogens, this translocation is also beneficial for providing resistance to pests such as wheat aphid (Schizaphis graminum Rondani) determined by the Gb2 and Gb6 genes, wheat curl mite (Aceria tosichella Keifer) conditioned by the $\mathrm{Cmc3}$ gene, English grain aphid (Sitobion avenae Fabricius) and bird cherry-oat aphid (Rhopalosiphum padi Linnaeus), for which the genes have not yet been identified [54-56]. 1RS.1DL translocation introduced another rust resistance gene (Sr50) into wheat [57]. Wheat lines containing 1R (1D) substitutions showed an increased resistance to English grain aphid and bird cherry-oat aphid. However, the genetic basis of this resistance has not yet been established [56,58]. In turn, 1R (1B) substitution resulted in an increased allelopathic activity against weeds [59].

It is also interesting to note the use of the wild species Secale africanum Stapf as a $1 \mathrm{R}^{\mathrm{afr}}$ donor. This species is characterised by an extremely high resistance to yellow rust [60]. All lines containing the $1 \mathrm{R}^{\text {afr }} \mathrm{S}$ chromosome arm introgression either in the form of disomic $1 \mathrm{R}^{\text {afr }} \mathrm{S}$ addition, $1 \mathrm{R}^{\text {afr }}(1 \mathrm{D})$ substitution or disomic, as well as monosomic, $1 \mathrm{R}^{\text {afr }} \mathrm{S} .1 \mathrm{BL}$ translocation were immune or highly resistant to the highly virulent CYR32 race of yellow rust, which overcame the resistance provided by $Y_{r} 9$ originating from the cereale-1R [61]. Moreover, a high resistance to this pathogen was also observed in amphiploids formed with common wheat $\left(A A B B D D R^{\text {afr }} R^{\text {afr }}\right)$ and durum wheat $\left(A A B B R^{\text {afr }} R^{\text {afr }}\right)$. Noticeably, the introgression of $1 R^{\text {afr }} \mathrm{L}$ in the form of $1 D S .1 R^{\text {afr }} \mathrm{L}$ translocation and $1 \mathrm{R}^{\mathrm{afr}} \mathrm{L}$ monotelocentric addition resulted in a high susceptibility to the above pathogen race. Therefore, it can be speculated that the $1 \mathrm{R}^{\text {afr }} \mathrm{S}$ contains a novel so-far unidentified yellow rust resistance gene (s) and may be applicable in wheat improvement programs [61].

\subsubsection{Resistance to Abiotic Factors}

The introgression of 1RS is helpful in improving wheat resistance to drought stress. The presence of 1RS.1BL translocation causes a significant increase in root length [62]. This trait improves the water and minerals uptake from deeper soil layers, resulting in increased drought tolerance [63]. Totally, 15 quantitative trait loci (QTL) regions (six additive and nine epistatic) were detected in the rye chromosome arm of the 1RS.1BL translocation line. Three of the four QTL regions for the root traits were located in the distal rye segment of the 1RLregion; the presence of this fragment significantly increased the root biomass in the 1RL.1BL translocation line [64,65].

The 1RS.BL translocation lines performed better than the normal 1BL lines under water deficit conditions, especially in terms of the growth rate [66,67]. The proline content was also higher in the translocation line under both the control and drought stress conditions [68]. Proline plays a key role in plant stress tolerance. It removes reactive oxygen species and, as a molecular chaperone, enables enzymes activity [69]. A high frequency of 1RS.1BL translocation was observed among Iranian dryland wheat lines, which may indicate that their drought stress tolerance is determined by transferred rye genes [70].

In addition to a wide range of resistance to abiotic and biotic factors, the 1RS introgression into the wheat genome improved the responsiveness of genotypes in an in vitro culture by enhancing the callus growth, somatic embryogenesis and regeneration of the 
microspore-derived haploid embryos [71-74]. The "Bobwhite" cultivar model in a wheat tissue culture and transformation study actually contained 1RS.1BL translocation [75].

\subsubsection{Agronomic Traits}

In general, the presence of 1RS.1BL translocation is associated with a significant yield increase. Higher aboveground biomass at maturity, higher grain number per spikelet and higher spikelet number per spike, as well as a higher test weight and 1000-grain weight, were observed $[76,77]$. The most recent studies also indicated that the presence of this translocation causes an increase in grain length [78]. It has also been suggested that a higher yield was associated with post-anthesis stress tolerance, which increased the grain weight [79]. However, some studies suggested a lack of yield increase in the lines containing 1RS.1BL translocation [80-83]. It appeared that there was a significant interaction between the grain yield and the rye and wheat genotypes that were used for production of the translocation lines [38,39]. It was also pointed out that the lines with 1RS.1BL translocation had the highest yields, while those with 1RS.1DL had the lowest among the homoeologous series of 1RS translocations [84]. However, further studies have shown that the influence of the rye chromatin source may be more crucial than its position in the wheat genome [44]. The presence of 1RS.1BL translocation was also linked to the "stay green" phenotype [85]. The delay of leaf aging after flowering and, therefore, the prolonged delivery of assimilated carbon to the grain play a key role in increasing the productivity [86].

\subsubsection{End-Use Quality}

Despite the fact that introgression brings a number of advantages discussed above related to the increase in resistance to biotic and abiotic factors, it significantly reduces the baking quality. This is due to the introduction the Sec-1 locus encoding $\omega$-secalins, i.e., rye storage proteins, into the wheat genome and the simultaneous loss of the Glu-3 loci encoding glutenins and the Gli-1 loci encoding gliadins [87]. An imbalance in the ratio of monomeric and polymeric proteins is reflected in the stickiness and weakness of the dough [88-90]. Glutenins have a positive effect on dough development time and loaf volume, while gliadins affect the loaf volume potential and dough viscosity [88,89,91-94]. Since the occurrence of Sec-1 locus coincides with the loss of the Gli-1 and Glu-3 loci, it is difficult to ascertain whether the absence of wheat glutenins and gliadins, the presence of rye secalins or a combination of both significantly reduces the wheat dough quality, as manifested by a low bread volume, poor mixing tolerance and dough stickiness $[88,93,95]$. Several studies indicated that 1RS.1AL translocation negatively affected the baking quality to a lesser extent compared to 1RS.1BL and 1RS.1DL $[84,96,97]$. Furthermore, the reduction of glutenin was not as drastic in the presence of this translocation, and consequently, a lower dough strength reduction was observed $[98,99]$. The 1RS.1BL translocation had a significant negative effect on the kernel hardness and test weight, sedimentation volume and tractility [76]. Grains from the $1 \mathrm{R}(1 \mathrm{~B})$ substitution lines were even softer than those from lines containing the 1RS.1BL translocation [100]. In durum wheat, the 1RS.1BL translocation had no effect on the grain protein content but a decreased gluten content, swelling index of the glutenins and reduced micro-SDS sedimentation volume were observed [90].

The 1RS whole-chromosome arm substitutions into wheat proved to be surprisingly successful if compared with other similar-type substitutions in plants. No other case was reported for a similar wide spontaneous spread-out of such large alien chromosome fragment into cereal breeding materials, which are subjected to strong selection pressure for yields. Among the conducive conditions for such a transfer are a high level of retained chromosome homology, lack of undesirable "wild" effects from the cultivated donor species and a high buffering capacity of the wheat polyploid genome. The decrease of baking quality is the only serious problem, which was extensively studied using chromosome engineering methods $[19,101]$. The first attempts to replace the Sec-1 rye gene with the Gli-B1+GluB3 wheat ones revealed nonallelic positions of the wheat and rye genes and 
a troublesome linkage with a set of desirable resistance genes (Pm8, Lr26, Yr9 and Sr31) located between the storage protein loci that had to be exchanged. In the next round of crossing-over stimulation (at the absence of the Ph1-pairing homoeology control gene from the wheat $5 \mathrm{~B}$ chromosome), the double-recombinant chromosome was selected that contained two small intercalary insertions and all the desired wheat and rye alleles [101]. However, another unexpected linkage emerged between the Sec-1 allele and genetic factors controlling the root system efficiency, being the main advantage of the 1RS.1BL substitution after the disease resistances were broken [19]. The next round of cytogenetic work was necessary to overcome this linkage. Similar inputs of work were necessary in another series of genetic engineering experiments with 1RS.1DL translocation on breaking the linkage between the Sec-1 locus and the locus for stem rust resistance [102]. The aim was to transfer to wheat a possibly small rye chromosome fragment containing the stem rust resistance gene and lacking the $S e c-1$ gene while retaining the wheat gliadin Gli-D1 gene. Success required 20 years and three rounds of chromosome engineering procedures (based also on the Ph1/ph1 system) [103]. Generally, the induced homoeologous recombination approaches required a large input of time and labour but provided a higher guarantee of final success than the competitive methods based on chromosome fragmentation like irradiation [104] or the use of gametocidal chromosomes [21]. Such procedures are simpler, but the chances to get a genetically balanced introgression are small. As a rule, the transferred fragments are built in random positions and are of non-compensating types that seldom exert no negative effects on the yield [19]. The ongoing progress in genome mapping and recombinant DNA technology gives hope for a more quick and precise transfer of desirable genes.

\subsection{Chromosome $2 R$}

Several attempts have been made to use chromosome $2 R$ for wheat improvement. Apart from S. cereale, Secale africanum Stapf. has also been used [105].

\subsubsection{Resistance to Biotic Factors}

The use of $2 \mathrm{R}$ resulted in an improved wheat resistance to brown rust. Its genetic background is diverse. The Lr45 gene was introduced through the 2AS-2RS.2RL and Lr25 through the 4BS.4BL-2RL translocation [42,106,107]. However, the genetic background of resistance to brown rust, which was introduced by the 2BS.2RL translocation, has not been identified [108]. The resistance to stem rust was obtained in lines containing the 2DS.2RL (Sr59) and 2BS.2RL (unknown gene) translocations [108,109]. Moreover, lines containing the $2 \mathrm{R}(2 \mathrm{~B})$ and $2 \mathrm{R}(2 \mathrm{D})$ disomic substitutions were highly resistant to stem rust at both the seedling and adult plant stages, and this resilience is likely to be determined by the novel gene(s) [110]. An increased resistance to powdery mildew was observed in translocation lines containing 4BS.4BL-2RL ( $\mathrm{Pm} 7$ ) and 2BS.2RL (unknown gene), as well as in lines containing the disomic substitution 1R(1D)+2R-addition (PmJZHM2RLb) and substitution $2 \mathrm{R}(2 \mathrm{D})$ (unknown gene) $[42,108,111,112]$. The use of the $2 \mathrm{R}^{\mathrm{afr}}$ introgression from S. africanum provided a resistance to yellow rust [105]. An increased resistance to this pathogen was observed in the $2 R^{\text {afr }}$ addition, $2 R^{\text {afr }}(2 D)$ substitution and $2 D S .2 R^{\text {afr }} L$ translocation lines. Since the resistance determined by $Y r 9$ located on 1RS has already been overcome, lines containing $2 \mathrm{R}^{\text {afr }} \mathrm{L}$ could be a valuable input for wheat resistance breeding [105]. The 2BS.2RL translocation also increased the resistance to the Hessian fly (Mayetiola destructor Say) that is determined by the $H 21$ gene [42,113]. Furthermore, $2 \mathrm{R}$ introgression also induced a high allelopathic activity and improved the ability of wheat to suppress weeds [59].

\subsubsection{Resistance to Abiotic Factors}

$2 \mathrm{R}$ introgression is generally considered to improve drought tolerance in wheat. Wheat containing the $2 \mathrm{R}$ disomic addition had increased water efficiency and improved rooting characteristics [114]. The 2AS.2RL translocation also had improved water efficiency, especially under drought stress $[114,115]$. However, the improvement of drought tolerance 
is dependent on the genetic background of the wheat cultivar used and its interaction with the genes located on the 2RL segment of a particular rye cultivar [116].

\subsubsection{Agronomic Traits}

Similar to drought stress resistance, the final result for agronomic traits depends on the wheat and rye genotypes used and their interactions [116]. The presence of 2AS.2RL translocation increased the grain yield and shoot biomass at maturity, which was particularly noticeable under drought stress [114]. 2BS.2RL translocation increased the yield, shoot biomass, number of grains per spike and number of grains per plant but simultaneously delayed maturity and reduced the grain weight and harvest index [117]. However, in another experiment using a different set of wheat and rye cultivars, this translocation reduced the number of spikes, delayed maturation and increased the number of grains/spike under optimal irrigation conditions and reduced the number of spikes and the grain-filling period under drought conditions [116]. Moreover, the 2R-addition also reduced the pollen fertility [118]. Notably, the lines containing the $2 \mathrm{R}^{\mathrm{afr}}$ introgression from S. africanum had a significantly reduced plant height as a result of the presence of strong dwarf genes; additionally, elongated spikes, as well as a higher number of spikelets per spike and 1000-grain weight, were observed [105]. The results encourage the further use of innovative lines containing $2 \mathrm{R}^{\text {afr }}$ in wheat improvement.

\subsubsection{End-Use Quality}

Unlike $1 R$, the presence of $2 R$ does not have such a destructive effect on the end-use quality of the wheat grain [108]. None of the known genes encoding storage proteins are located on 2RL [75]. Although a reduced flour yield and grain hardness were observed in the lines containing the 2BS.2RL translocation, these weaknesses could be eliminated by an appropriate selection. In addition, a slight reduction in mixograph-mixing and bakemixing times were observed, but these did not significantly reduce the quality. However, an improvement in water absorption and flour colour was observed. On the other hand, there were no significant differences in the flour protein content, loaf volume or mixographmixing tolerance [119]. Due to the presence in both arms of the $2 \mathrm{R}$ of the factors responsible for the increase in soluble dietary fibre and arabinoxylans, their significant increase was observed in wheat lines containing $2 \mathrm{R}$ introgression [120].

\subsection{Chromosome $3 R$}

The use of chromosome $3 \mathrm{R}$ in wheat improvement programs is rather negligible. This could be due to the low 3R transmission in backcrossing [121]. The first obtained wheat translocation line containing $3 \mathrm{R}$ introgression turned out to be non-compensating and contained 3RS from rye and 3AS from wheat [122]. In later attempts, 3AL.3RS, 3BL.3RS, and 3DL.3RS translocations were successfully obtained [110,122].

\subsubsection{Resistance to Biotic Factors}

Segment 3RS contains the stem rust resistance gene Sr27 [123]. There is also a second gene on the $3 \mathrm{R}$ chromosome that determines a broad spectrum of resistances to stem rust. The $3 R(3 D)$ substitution lines were characterised by a high resistance to stem rust at the seedling stage, as determined by the SrSatu gene [124]. In one of the lines, the presence of an additional, unknown gene for stem rust resistance was also postulated [124]. In the lines containing the 3RS.3DL transcript, an increase in resistance to D. noxia was observed [125]. However, the genetic basis of this resistance remains unknown. Introgressions of $3 \mathrm{R}$ and 3RS also provided resistance to the Hessian fly [110].

\subsubsection{Resistance to Abiotic Factors}

Increased aluminium tolerance was observed in the $3 \mathrm{R}$ addition line. Twenty-seven upregulated genes have been identified in this line, possibly reflecting the induction of tolerance mechanisms [126]. 


\subsubsection{Agronomic Traits}

Unfortunately, both 3RS.3AL. and 3RS.3BL translocations resulted in a reduced yield and hectolitre test weight [127].

\subsubsection{End-Use Quality}

Little is known about the effect of 3R on the end-use quality. However, this chromosome does not contain any known genes that affect the flour quality and its breadmaking quality [127]. The lines containing $3 \mathrm{R}(3 \mathrm{~B})$ substitutions had high iron and zinc contents and, simultaneously, low cadmium contents [110].

\subsection{Chromosome $4 R$}

Due to the low homology and poorly conserved collinearity between rye $4 \mathrm{R}$ and wheat $4 \mathrm{~A}, 4 \mathrm{~B}$ and $4 \mathrm{D}$, there is a low recombination frequency and problems with compensation. Therefore, the use of $4 \mathrm{R}$ in wheat improvement is extremely difficult [27].

\subsubsection{Resistance to Biotic Factors}

The potential of this chromosome in wheat breeding is enormous and remains unexploited. This chromosome contains genes determining the resistance to diseases and pests such as brown rust (Pr-j and Pr-l) powdery mildew (Pm6), fusarium head blight and Diuraphis. noxia $[125,128-131]$. So far, it has been possible to exploit the powdery mildew resistance determined by a gene located on $4 \mathrm{R}$. The introgression of rye chromatin in the form of complex translocations 5DS-4RS.4RL, 4RS-5DS.5DL and 4BL.4RL + 4RS.7AS provided immunity, and cytologically stable lines were developed [132,133]. A resistance to powdery mildew, yellow rust and sharp eyespot (Rhizoctonia cerealis van der Hoeven), which is most likely determined by novel genes, was obtained in the $4 \mathrm{R}$ disomic addition line [134]. The 4R addition lines also contained the resistance gene Karnal bunt (Tilletia indica Mitra) [135]. There were attempts to transfer the resistance to Russian wheat aphid (D. noxia) with the use of irradiation and induce homoeologous recombination. The success was dubious; two resistant recombinants, carrying smaller introgressed rye fragments, were less viable and fertile than the donor 7DS.4RL ${ }^{\text {mon }}$ substitution line, resulting from an earlier centric translocation in a hybrid between wheat and perennial rye, Secale montanum. A low level of chromosome homology and structural differences between the donor and recipient chromosomes make rye-wheat chromosome engineering in group 4 extremely difficult [27].

\subsubsection{Resistance to Abiotic Factors}

Genes that determine drought tolerance, such as the relative water content and general adaptability, have also been localised on chromosome $4 \mathrm{R}$ in the disomic addition line [30].

\subsubsection{Agronomic Traits}

The presence of $4 \mathrm{R}$ introgression in the genetic background of wheat increased the number of spikelets and grains per spike, thousand-grain weight, anther size and pollen grain number, but it also caused an increase in plant height and susceptibility to lodging [134].

\subsubsection{End-Use Quality}

A higher grain protein content was observed in wheat lines containing the $4 \mathrm{R}$ addition, and the $1 \mathrm{R}+4 \mathrm{R}$ line had a high gluten strength [110]. Additionally, the addition of $4 \mathrm{R}$ originated from the perennial, hybrid rye Secale cereanum and increased the protein and arabinoxylan contents in wheat grain [136].

\subsection{Chromosome $5 R$}

The presence of a non-compensation and low recombination frequency problem has also been reported for chromosome $5 R$ and its wheat homologues [19,27]. Similar to $4 R$, this is a major factor limiting the use of valuable genes located on $5 \mathrm{R}$ in wheat improve- 
ment. The first report of spontaneous $5 \mathrm{R}(5 \mathrm{~A})$ substitution dates back to the late 1930 s and early 1940s [137,138].

\subsubsection{Resistance to Biotic Factors}

An increased resistance to powdery mildew has been observed in lines containing the 5RS.5AL and 5RS.5AL+1RS.1BL translocations, as well as the 5R single disomic substitution $[110,139]$. An increased resistance to yellow rust was noted in lines containing the translocations $5 R S .5 A L, 5 R S .5 A L+4 R+6 R$ and $5 R(5 D)$. These lines may be the source of novel resistance gene(s) against the pathogen causing this disease [110,140]. Xi et al. identified the presence of probable new gene(s) for the resistance to yellow rust in wheat lines containing the 5RL chromosome arm [141]. The introgression of the $5 \mathrm{R}^{\text {afr }}$ chromosome from S. africanum also incorporated the yellow rust resistance gene(s) [142]. Seedlings of lines containing the 5RS.5AL translocation were resistant to stem rust [124]. Furthermore, the presence of the $5 \mathrm{R}$ introgression correlated with reduced levels of septoria leaf blotch and fusarium head blight infection under field conditions [110,143]. Genes determining the resistance to D. noxia and M. destructor are also located on chromosome 5R and have been transferred with it to wheat $[110,125]$.

\subsubsection{Resistance to Abiotic Factors}

An increased tolerance for copper has been observed in wheat lines containing the $5 \mathrm{R}(5 \mathrm{~A})$ substitution $[144,145]$.

\subsubsection{Agronomic Traits}

In both lines containing the $5 R^{\text {afr }}(5 \mathrm{D})$ substitution and the $5 R^{\text {afr }}$ S.5DL translocation from S. africanum, an increase in spike length was observed [142]. An increased spike size and multispikelet formation were observed in the $5 R(5 A)$ and $5 R(5 D)$ substitution lines $[139,141]$. The substitution of $5 \mathrm{R}(5 \mathrm{~A})$ also resulted in a phenological period extension from germination to heading and a changed type from spring to winter compared to the wheat component due to the deletion of a single Vrn-A1 gene [139].

\subsubsection{End-Use Quality}

In the grain of wheat cv. "Viking", which contains 4BL.5RL translocation, high levels of iron, copper and zinc were detected [146]. Additionally, recent research indicates that grains of wheat lines containing $5 R$ introgression from rye have increased iron and zinc contents [110]. Both $5 R$ and $5 R^{\text {afr }}$ increased the grain protein content, whereas $5 R$ decreased the wheat grain hardness $[139,142]$.

\subsubsection{Others}

In the line containing the $5 \mathrm{R}(5 \mathrm{~A})$ substitution, a significant increase in the somatic embryogenesis parameters like callus formation and regeneration capacity was observed in the in vitro cultures of inflorescences [147].

\subsection{Chromosome 6R}

Several elite genes are located on chromosome 6R, but its exploitation in wheat breeding is hampered. The long arm of $6 R L$ causes a genetic imbalance in the wheat genome [148]. Lines containing small-segment introgressions like 6D.6RL ${ }^{\mathrm{Ku}}$ may provide a solution to this problem [51]. Chromosome 6R, like the discussed above 3R, shows a much lower transmission frequency compared to the other rye chromosomes [121].

\subsubsection{Resistance to Biotic Factors}

By introgressing $6 R$, it was possible to achieve an increased resistance of wheat to some fungal diseases, nematodes and pests. The disomic substitution of $6 \mathrm{R}(6 \mathrm{D})$ enabled the identification of $Y r 83$, a new gene determining the resistance to yellow rust [149]. The 6BS.6RL and 6RS.6AL translocations provided a powdery mildew resistance in wheat. 
This was determined by the Pm20 and Pm56 genes, respectively [150,151]. An increased resistance to powdery mildew was also observed in wheat lines containing the $6 \mathrm{D} .6 \mathrm{RL} \mathrm{Ku}$ translocation with the rye minichromosome, $1 \mathrm{R}+6 \mathrm{R}$ substitution, $6 \mathrm{R}$ disomic addition and 6RL monotelosomic or ditelosomic addition [51,110,133,148,152]. The presence of the $1 \mathrm{R}+6 \mathrm{R}$ substitution was also associated with decreased infection levels by pathogens causing septoria leaf blotch and fusarium head blight, stem rust and yellow rust in wheat [110]. The same research team observed an increased resistance to Diuraphis noxia and Mayetiola destructor in wheat lines containing $1 \mathrm{R}+6 \mathrm{R}$ substitutions [110]. A Hessian fly resistance determined by the $H 25$ gene was found in the translocation line 4BS.4BL-6RL produced with the use of irradiation [42]. Progress in nematode resistance breeding against Heterodera avenae and Heterodera filipjevi may be achieved by using both the 6DS.6RL translocation and the $6 \mathrm{R}(6 \mathrm{D})$ substitution lines containing the CreR gene for resistance to cereal cyst nematode [26,153]. The $6 \mathrm{R}$ introgression in wheat also improved its allelopathic activity and weed suppressive ability [59].

\subsubsection{Agronomic Traits}

The evaluation of agronomic traits was performed for a substitution line 6R(6A). It had a strong stem, high spike density, high yield and low satiation grain [154].

\subsection{Chromosome $7 R$}

Chromosome 7R has not been used in wheat breeding programs, although it contains genes for resistances to brown rust, stem rust and D. noxia $[128,155,156]$. This is due to the low degree of homology to group 7 chromosomes in wheat. However, the addition of the single rye chromosome $7 \mathrm{R}$ significantly increased the $D$. noxia resistance of the recipient wheat [156]. The $7 \mathrm{R}$ disomic addition line of wheat showed an improved drought resistance [157]. Moreover, the $7 R$ addition wheat line had a reduced severity of zinc deficiency symptoms [158].

\section{Rye Genetic Resources and Perspective for Their Use in Wheat Breeding}

The global collection of the genus Secale genetic resources currently comprises 27,547 accessions and includes five species. The most numerous is the gene pool of the only cultivated species, S. cereale. This collection comprises 18,499 accessions, of which $68.8 \%$ are preserved in European gene banks. Thirty-sex point eight percent of the collected accessions are traditional varieties and landraces [159]. Rye is an open-pollinated species with high genetic variation among individuals. This variation occurs not only within landraces but, also, in old commercial cultivars [160,161]. Studies evaluating the rye gene pool, including molecular studies, are becoming increasing common [162-166]. Despite the availability of high-throughput genotyping and phenotyping methods, a considerable number of accessions have not been characterised even to a minimal extent. This significantly hinders their use in breeding programs. Considering the high resistance of rye to biotic and abiotic stresses and the possibility of its chromatin introgression into the wheat genome, the collected genetic resources seem to be an exceptional and relatively poorly exploited reservoir of genetic variability for wheat breeding programs. However, the intensification of multilevel studies characterising the accessions stored in gene banks is a prerequisite for researchers and, later, also breeders and farmers to be able to take advantage of this valuable reservoir.

\section{Future in the Hands of Molecular Biologist}

The introgressions of rye chromatin fragments into wheat described in this paper were achieved using chromosome engineering techniques. These results were obtained by cytological methods and a titanic amount of work over a microscope. The dynamic development of genetic engineering techniques allows to assume that the future of interspecies gene transfers will belong to them. Of particular note are techniques such as RNA interference (RNAi) gene silencing and genome editing using zinc-finger nucleases 
(ZFNs), transcription activator-like effector nucleases (TALENs) and, especially, nucleasedeactivated Cas9 (CRISPR/Cas9) $[167,168]$. The first steps in this direction have already been taken and, at least in a few cases, have been successful $[169,170]$. The application of CRISPR/Cas9 targeting the ZIP4 gene located at the Ph1 locus in wheat resulted in a significant increase in the frequency of homoeologous crossing-over in hybridisations with rye [171]. Understanding the mechanisms regulating chromosome pairing in different species still needs some work. However, it should be recognised that the development of tools to increase the frequency of crossing-over between chromosomes of cultivated species and their wild relatives has the potential to become an essential instrument for accelerating breeding and increasing the introgression precision of desired alleles and genes.

Author Contributions: Conceptualisation, M.B. and K.M.; writing-original draft preparation, M.B., B.Ł., K.M. and S.K.; writing-review and editing, B.Ł. and W.P. and funding acquisition, W.P. All authors have read and agreed to the published version of the manuscript.

Funding: This research received no external funding.

Institutional Review Board Statement: Not applicable.

Informed Consent Statement: Not applicable.

Data Availability Statement: Not applicable.

Conflicts of Interest: The authors declare no conflict of interest.

\section{References}

1. Tadesse, W.; Amri, A.; Ogbonnaya, F.C.; Sanchez-Garcia, M.; Sohail, Q.; Baum, M. Wheat. In Genetic and Genomic Resources for Grain Cereals Improvement; Singh, M., Upadhyaya, H.D., Eds.; Elsevier: Amsterdam, The Netherlands, 2016; pp. 81-124.

2. Nuttonson, M. Wheat-Climatic Relationships and the Use of Phenology in Ascertaining the Thermal and Photo-thermal Requirements of Wheat; American Institute of Crop Ecology: Washington, DC, USA, 1955.

3. Baum, M.; Tadesse, W.; Nachit, M.; Abdalla, O.; Rajaram, S.; Singh, R.; Payne, T.; Ammar, K.; Morgounov, A.; Braun, H. Global crop improvement networks to bridge technology gaps. In Advances in Wheat Genetics: From Genome to Field; Springer: Tokyo, Japan, 2015; pp. 387-399.

4. Feldman, M.; Levy, A.A. Genome evolution due to allopolyploidization in wheat. Genetics 2012, 192, 763-774. [CrossRef]

5. Luo, M.-C.; Gu, Y.Q.; Puiu, D.; Wang, H.; Twardziok, S.O.; Deal, K.R.; Huo, N.; Zhu, T.; Wang, L.; Wang, Y. Genome sequence of the progenitor of the wheat D genome Aegilops tauschii. Nature 2017, 551, 498-502. [CrossRef]

6. Feldman, M.; Lupton, F.; Miller, T. Evolution of Crop Plants; Smartt, J., Simmonds, N.W., Eds.; Longman Scientific \& Technical: Harlow Essex, UK, 1995; pp. 184-192.

7. Huang, S.; Sirikhachornkit, A.; Su, X.; Faris, J.; Gill, B.; Haselkorn, R.; Gornicki, P. Genes encoding plastid acetyl-CoA carboxylase and 3-phosphoglycerate kinase of the Triticum/Aeg+ilops complex and the evolutionary history of polyploid wheat. Proc. Natl. Acad. Sci. USA 2002, 99, 8133-8138. [CrossRef]

8. Sears, E.R. The Aneuploids of Common Wheat. Research Bulletin 572; University of Missouri, College of Agriculture, Agricultural Experiment Station: Columbia, MO, USA, 1954; pp. 3-54.

9. Flavell, R. Sequence amplification, deletion and rearrangement: Major sources of variation during species divergence. In Genome Evolution; Dover, G.A., Flavell, R.B., Eds.; Published for the Systematics Association by Academic Press: London, UK, 1982; pp. 301-323.

10. Wicker, T.; Mayer, K.F.; Gundlach, H.; Martis, M.; Steuernagel, B.; Scholz, U.; Šimková, H.; Kubaláková, M.; Choulet, F.; Taudien, $\mathrm{S}$. Frequent gene movement and pseudogene evolution is common to the large and complex genomes of wheat, barley, and their relatives. Plant Cell 2011, 23, 1706-1718. [CrossRef] [PubMed]

11. Faris, J.; Friebe, B.; Gill, B. Wheat genomics: Exploring the polyploid model. Curr. Genom. 2002, 3, 577-591. [CrossRef]

12. Matsuoka, Y. Evolution of polyploid Triticum wheats under cultivation: The role of domestication, natural hybridization and allopolyploid speciation in their diversification. Plant Cell Physiol. 2011, 52, 750-764. [CrossRef]

13. Middleton, C.P.; Senerchia, N.; Stein, N.; Akhunov, E.D.; Keller, B.; Wicker, T.; Kilian, B. Sequencing of chloroplast genomes from wheat, barley, rye and their relatives provides a detailed insight into the evolution of the Triticeae tribe. PLoS ONE 2014, 9, e85761. [CrossRef]

14. Sears, E.R. Genetic control of chromosome pairing in wheat. Annu. Rev. Genet. 1976, 10, 31-51. [CrossRef] [PubMed]

15. Harlan, J.R.; de Wet, J.M. Toward a rational classification of cultivated plants. Taxon 1971, 20, 509-517. [CrossRef]

16. Jiang, J.; Friebe, B.; Gill, B.S. Recent advances in alien gene transfer in wheat. Euphytica 1993, 73, 199-212. [CrossRef]

17. Feuillet, C.; Langridge, P.; Waugh, R. Cereal breeding takes a walk on the wild side. Trends Genet. 2008, 24, 24-32. [CrossRef]

18. Schlegel, R.H. Rye: Genetics, Breeding, and Cultivation; CRC Press: Boca Raton, FL, USA, 2013. 
19. Lukaszewski, A.J. Introgressions between wheat and rye. In Alien Introgression in Wheat; Springer: Cham, Switzerland, 2015; pp. 163-189.

20. Molnár-Láng, M.; Molnár, I.; Szakács, É.; Linc, G.; Bedö, Z. Production and molecular cytogenetic identification of wheat-alien hybrids and introgression lines. In Genomics of Plant Genetic Resources; Springer: Dordrecht, The Netherlands, 2014 ; pp. 255-283.

21. Endo, T. The gametocidal chromosome as a tool for chromosome manipulation in wheat. Chromosome Res. 2007, 15, 67-75. [CrossRef]

22. Rather, S.A.; Sharma, D.; Pandey, I.; Joshi, N. Alien gene introgression in wheat. In Wheat a Premier Food Crop; Kumar, A., Kumar, A., Prasad, B., Eds.; Kalyani Publishers: Delhi, India, 2017; pp. 90-109.

23. Bauer, E.; Schmutzer, T.; Barilar, I.; Mascher, M.; Gundlach, H.; Martis, M.M.; Twardziok, S.O.; Hackauf, B.; Gordillo, A.; Wilde, P. Towards a whole-genome sequence for rye (Secale cereale L.). Plant J. 2017, 89, 853-869. [CrossRef]

24. Naranjo, T.; Fernández-Rueda, P. Homoeology of rye chromosome arms to wheat. Theor. Appl. Genet. 1991, 82, 577-586. [CrossRef]

25. Devos, K.M.; Atkinson, M.; Chinoy, C.; Francis, H.; Harcourt, R.; Koebner, R.; Liu, C.; Masojć, P.; Xie, D.; Gale, M. Chromosomal rearrangements in the rye genome relative to that of wheat. Theor. Appl. Genet. 1993, 85, 673-680. [CrossRef] [PubMed]

26. Dundas, I.S.; Frappell, D.E.; Crack, D.M.; Fisher, J.M. Deletion mapping of a nematode resistance gene on rye chromosome 6R in wheat. Crop Sci. 2001, 41, 1771-1778. [CrossRef]

27. Lukaszewski, A.J.; Porter, D.R.; Baker, C.A.; Rybka, K.; Lapinski, B. Attempts to transfer Russian wheat aphid resistance from a rye chromosome in Russian triticales to wheat. Crop Sci. 2001, 41, 1743-1749. [CrossRef]

28. Ko, J.; Seo, B.; Suh, D.; Do, G.; Park, D.; Kwack, Y. Production of a new wheat line possessing the 1BL. 1RS wheat-rye translocation derived from Korean rye cultivar Paldanghomil. Theor. Appl. Genet. 2002, 104, 171-176. [CrossRef]

29. Braun, H.; Payne, T.; Morgounov, A.; Van Ginkel, M.; Rajaram, S. The challenge: One billion tons of wheat by 2020. In Proceedings of the 9th International Wheat Genetic Symposium, Saskatoon, SK, Canada, 2-7 August 1998; pp. 2-7.

30. Kőszegi, B.; Linc, G.; Juhász, L.; Lang, L.; Molnar-Lang, M. Occurrence of the 1Rs/1Bl wheat-rye translocation in Hungarian wheat varieties. Acta Agron. Hung. 2000, 48, 227-236. [CrossRef]

31. Rabinovich, S.V. Importance of wheat-rye translocations for breeding modern cultivar of Triticum aestivum L. Euphytica 1998, 100, 323-340. [CrossRef]

32. Yediay, F.E.; Baloch, F.S.; Kilian, B.; Özkan, H. Testing of rye-specific markers located on 1RS chromosome and distribution of $1 \mathrm{AL}$. RS and 1BL. RS translocations in Turkish wheat (Triticum aestivum L., T. durum Desf.) varieties and landraces. Genet. Resour. Crop Evol. 2010, 57, 119-129. [CrossRef]

33. Schlegel, R.; Korzun, V. About the origin of 1RS. 1BL wheat-rye chromosome translocations from Germany. Plant Breed. 1997, 116, 537-540. [CrossRef]

34. Friebe, B.; Zeller, F.; Kunzmann, R. Transfer of the 1BL/1RS wheat-rye-translocation from hexaploid bread wheat to tetraploid durum wheat. Theor. Appl. Genet. 1987, 74, 423-425. [CrossRef] [PubMed]

35. Zeller, F.J.; Hsam, S.L. Broadening the genetic variability of cultivated wheat by utilizing rye chromatin. In Proceedings of the Sixth International Wheat Genetics Symposium, Kyoto, Japan, 28 November-3 December 1983.

36. Martin, T.; Harvey, T.; Bender, C.; Seifers, D.; Hatchett, J. Wheat curl mite resistant wheat germplasm. Crop Sci. 1983, $23,809$. [CrossRef]

37. Ren, T.; Ren, Z.; Yang, M.; Yan, B.; Tan, F.; Fu, S.; Tang, Z.; Li, Z. Novel source of 1RS from Baili rye conferred high resistance to diseases and enhanced yield traits to common wheat. Mol. Breed. 2018, 38, 101. [CrossRef]

38. Ren, T.; Tang, Z.; Fu, S.; Yan, B.; Tan, F.; Ren, Z.; Li, Z. Molecular cytogenetic characterization of novel wheat-rye T1RS. 1BL translocation lines with high resistance to diseases and great agronomic traits. Front. Plant Sci. 2017, 8, 799. [CrossRef]

39. Ren, T.-H.; Chen, F.; Yan, B.-J.; Zhang, H.-Q.; Ren, Z.-L. Genetic diversity of wheat-rye 1BL. 1RS translocation lines derived from different wheat and rye sources. Euphytica 2012, 183, 133-146. [CrossRef]

40. Schlegel, R. Current List of Wheats with Rye and Alien Introgression; V08-19. Available online: http:/ / www.rye-gene-map.de/ rye-introgression/ (accessed on 15 January 2021).

41. Sebesta, E.; Wood, E., Jr.; Porter, D.; Webster, J.; Smith, E. Registration of amigo wheat germplasms resistant to greenbug. Crop Sci. 1995, 35, 293. [CrossRef]

42. Friebe, B.; Jiang, J.; Raupp, W.; McIntosh, R.; Gill, B. Characterization of wheat-alien translocations conferring resistance to diseases and pests: Current status. Euphytica 1996, 91, 59-87. [CrossRef]

43. Porter, D.; Webster, J.; Burton, R.; Smith, E. Registration of GRS1201 greenbug multi-biotype-resistant wheat germplasm. Crop Sci. 1993, 33, 1115. [CrossRef]

44. Kim, W.; Johnson, J.; Baenziger, P.; Lukaszewski, A.; Gaines, C. Agronomic effect of wheat-rye translocation carrying rye chromatin (1R) from different sources. Crop Sci. 2004, 44, 1254-1258. [CrossRef]

45. Lukaszewski, A.J. Reconstruction in wheat of complete chromosomes 1B and 1R from the 1RS. 1BL translocation of 'Kavkaz'origin. Genome 1993, 36, 821-824. [CrossRef]

46. Hanušová, R.; Hsam, S.; Bartoš, P.; Zeller, F. Suppression of powdery mildew resistance gene Pm8 in Triticum aestivum L.(common wheat) cultivars carrying wheat-rye tranlocation T1BL.1RS. Heredity 1996, 77, 383-387. [CrossRef]

47. Qi, W.; Tang, Y.; Zhu, W.; Li, D.; Diao, C.; Xu, L.; Zeng, J.; Wang, Y.; Fan, X.; Sha, L. Molecular cytogenetic characterization of a new wheat-rye 1BL・1RS translocation line expressing superior stripe rust resistance and enhanced grain yield. Planta 2016, 244, 405-416. [CrossRef] 
48. Singh, R.P.; Hodson, D.P.; Jin, Y.; Huerta-Espino, J.; Kinyua, M.G.; Wanyera, R.; Njau, P.; Ward, R.W. Current status, likely migration and strategies to mitigate the threat to wheat production from race Ug99 (TTKS) of stem rust pathogen. Cab Rev. Perspect. Agric. Vet. Sci. Nutr. Nat. Resour. 2006, 1, 1-13. [CrossRef]

49. Singh, R.P.; Hodson, D.P.; Huerta-Espino, J.; Jin, Y.; Bhavani, S.; Njau, P.; Herrera-Foessel, S.; Singh, P.K.; Singh, S.; Govindan, V. The emergence of Ug99 races of the stem rust fungus is a threat to world wheat production. Annu. Rev. Phytopathol. 2011, 49, 465-481. [CrossRef]

50. Yang, E.; Li, G.; Li, L.; Zhang, Z.; Yang, W.; Peng, Y.; Zhu, Y.; Yang, Z.; Rosewarne, G.M. Characterization of stripe rust resistance genes in the wheat cultivar Chuanmai45. Int. J. Mol. Sci. 2016, 17, 601. [CrossRef]

51. Li, M.; Tang, Z.; Qiu, L.; Wang, Y.; Tang, S.; Fu, S. Identification and physical mapping of new PCR-based markers specific for the long arm of rye (Secale cereale L.) chromosome 6. J. Genet. Genom. 2016, 43, 199-206. [CrossRef] [PubMed]

52. Lapitan, N.L.; Peng, J.; Sharma, V. A high-density map and PCR markers for Russian wheat aphid resistance gene Dn7 on chromosome 1RS/1BL. Crop Sci. 2007, 47, 811-818. [CrossRef]

53. Mohler, V.; Hsam, S.; Zeller, F.; Wenzel, G. An STS marker distinguishing the rye-derived powdery mildew resistance alleles at the Pm8/Pm17 locus of common wheat. Plant Breed. 2001, 120, 448-450. [CrossRef]

54. Malik, R.; Brown-Guedira, G.; Smith, C.; Harvey, T.; Gill, B. Genetic mapping of wheat curl mite resistance genes Cmc3 and Cmc4 in common wheat. Crop Sci. 2003, 43, 644-650. [CrossRef]

55. Lu, H.; Rudd, J.C.; Burd, J.; Weng, Y. Molecular mapping of greenbug resistance genes Gb2 and Gb6 in T1AL. 1RS wheat-rye translocations. Plant Breed. 2010, 129, 472-476.

56. Crespo-Herrera, L.A.; Smith, C.M.; Singh, R.P.; Åhman, I. Resistance to multiple cereal aphids in wheat-alien substitution and translocation lines. Arthropod-Plant Interact. 2013, 7, 535-545. [CrossRef]

57. Mago, R.; Zhang, P.; Vautrin, S.; Šimková, H.; Bansal, U.; Luo, M.-C.; Rouse, M.; Karaoglu, H.; Periyannan, S.; Kolmer, J. The wheat Sr50 gene reveals rich diversity at a cereal disease resistance locus. Nat. Plants 2015, 1, 1-3. [CrossRef]

58. Lukaszewski, A.J. Cytogenetically engineered rye chromosomes $1 \mathrm{R}$ to improve bread-making quality of hexaploid triticale. Crop Sci. 2006, 46, 2183-2194. [CrossRef]

59. Bertholdsson, N.O.; Andersson, S.C.; Merker, A. Allelopathic potential of Triticum spp., Secale spp. and Triticosecale spp. and use of chromosome substitutions and translocations to improve weed suppression ability in winter wheat. Plant Breed. 2012, 131, 75-80. [CrossRef]

60. Lei, M.; Li, G.; Zhang, S.; Liu, C.; Yang, Z. Molecular cytogenetic characterization of a new wheat Secale africanum 2R a (2D) substitution line for resistance to stripe rust. J. Genet. 2011, 90, 283-287. [CrossRef] [PubMed]

61. Lei, M.-P.; Li, G.-R.; Liu, C.; Yang, Z.-J. Characterization of wheat-Secale africanum introgression lines reveals evolutionary aspects of chromosome $1 \mathrm{R}$ in rye. Genome 2012, 55, 765-774. [CrossRef] [PubMed]

62. Liu, H.; Tang, H.; Ding, P.; Mu, Y.; Habib, A.; Liu, Y.; Jiang, Q.; Chen, G.; Kang, H.; Wei, Y. Effects of the 1BL/1RS translocation on 24 traits in a recombinant inbred line population. Cereal Res. Commun. 2020, 48, 225-232. [CrossRef]

63. Ludlow, M.; Muchow, R. A critical evaluation of traits for improving crop yields in water-limited environments. In Advances in Agronomy; Elsevier: Amsterdam, The Netherlands, 1990; Volume 43, pp. 107-153.

64. Sharma, S.; Xu, S.; Ehdaie, B.; Hoops, A.; Close, T.J.; Lukaszewski, A.J.; Waines, J.G. Dissection of QTL effects for root traits using a chromosome arm-specific mapping population in bread wheat. Theor. Appl. Genet. 2011, 122, 759-769. [CrossRef]

65. Sharma, A.; Sheikh, I.; Kumar, R.; Kumar, K.; Vyas, P.; Dhaliwal, H. Evaluation of end use quality and root traits in wheat cultivars associated with 1RS. 1BL translocation. Euphytica 2018, 214, 62. [CrossRef]

66. Carver, B.; Rayburn, A.; Hunger, R.; Smith, E.; Whitmore, W. Registration of 1B versus 1RS. 1BL near-isoline genetic stocks from two hard red winter wheat populations. Crop Sci. 1993, 33, 1120. [CrossRef]

67. Hoffmann, B. Alteration of drought tolerance of winter wheat caused by translocation of rye chromosome segment 1RS. Cereal Res. Commun. 2008, 36, 269-278. [CrossRef]

68. Jang, J.H.; Jung, W.J.; Kim, D.Y.; Seo, Y.W. cDNA-AFLP analysis of 1BL. 1RS under water-deficit stress and development of wheat-rye translocation-specific markers. N. Zeal. J. Crop Hortic. Sci. 2017, 45, 150-164. [CrossRef]

69. Szabados, L.; Savoure, A. Proline: A multifunctional amino acid. Trends Plant Sci. 2010, 15, 89-97. [CrossRef]

70. Golkari, S.; Hasaniani, A. Molecular evaluation of 1RS-rye translocation distribution in the Iranian dryland wheat cultivars and elite promising lines. Iran. J. Field Crop Sci. 2017, 48, 119-128.

71. Henry, Y.; Bernard, S.; Bernard, M.; Gay, G.; Marcotte, J.-L.; Buyser, J.D. Nuclear gametophytic genes from chromosome arm 1RS improve regeneration of wheat microspore-derived embryos. Genome 1993, 36, 808-814. [CrossRef] [PubMed]

72. Langridge, P.; Lazzeri, P.; Lörz, H. A segment of rye chromosome 1 enhances growth and embryogenesis of calli derived from immature embryos of wheat. Plant Cell Rep. 1991, 10, 148-151. [CrossRef] [PubMed]

73. Lazaridou, T.B.; Pankou, C.I.; Xynias, I.; Roupakias, D. Effect of the 1BL. 1RS wheat-rye translocation on the androgenic response in spring bread wheat. Cytol. Genet. 2017, 51, 485-490. [CrossRef]

74. Agache, S.; Bachelier, B.; De Buyser, J.; Henry, Y.; Snape, J. Genetic analysis of anther culture response in wheat using aneuploid, chromosome substitution and translocation lines. Theor. Appl. Genet. 1989, 77, 7-11. [CrossRef]

75. Graybosch, R.A. Mini review: Uneasy unions: Quality effects of rye chromatin transfers to wheat. J. Cereal Sci. 2001, 33, 3-16. [CrossRef] 
76. Zhao, C.; Cui, F.; Wang, X.; Shan, S.; Li, X.; Bao, Y.; Wang, H. Effects of 1BL/1RS translocation in wheat on agronomic performance and quality characteristics. Field Crop. Res. 2012, 127, 79-84. [CrossRef]

77. Villareal, R.L.; Mujeeb-Kazi, A.; Rajaram, S.; Del Toro, E. Associated effects of chromosome 1B/1R translocation on agronomic traits in hexaploid wheat. Jpn. J. Breed. 1994, 44, 7-11. [CrossRef]

78. Li, S.Q.; Tang, H.P.; Zhang, H.; Mu, Y.; Lan, X.J.; Ma, J. A 1BL/1RS translocation contributing to kernel length increase in three wheat recombinant inbred line populations. Czech J. Genet. Plant Breed. 2020, 56, 43-51. [CrossRef]

79. Moreno-Sevilla, B.; Baenziger, P.; Peterson, C.; Graybosch, R.; McVey, D. The 1BL/1RS translocation: Agronomic performance of F3-derived lines from a winter wheat cross. Crop Sci. 1995, 35, 1051-1055. [CrossRef]

80. McKendry, A.; Tague, D.; Miskin, K. Effect of 1BL. 1RS on agronomic performance of soft red winter wheat. Crop Sci. 1996, 36, 844-847. [CrossRef]

81. Singh, R.; Huerta-Espino, J.; Rajaram, S.; Crossa, J. Agronomic effects from chromosome translocations 7DL. 7Ag and 1BL. 1RS in spring wheat. Crop Sci. 1998, 38, 27-33. [CrossRef]

82. Xynias, I.N.; Tasios, I.E.; Korpetis, E.G.; Pankou, C.; Avdikos, I.; Mavromatis, A.G. Effect OF the 1BL. 1RS wheat-rye chromosomal translocation on yield potential in bread wheat. Agric. For. 2020, 66, 15-22. [CrossRef]

83. Xynias, I.N.; Mavromatis, A.G.; Pankou, C.I.; Koutsoura, T.; Kyparissas, D.; Liliopoulou, E.; Priami, M.; Tasios, I.; Trakosiaris, D.; Papathanasiou, F. Effect of the 1BL. 1RS wheat-rye translocation on qualitative traits in bread wheat. Agric. For. 2018, 64, 15. [CrossRef]

84. Kumlay, A.; Baenziger, P.S.; Gill, K.; Shelton, D.; Graybosch, R.A.; Lukaszewski, A.; Wesenberg, D. Understanding the effect of rye chromatin in bread wheat. Crop Sci. 2003, 43, 1643-1651. [CrossRef]

85. Luo, P.; Zhang, H.; Shu, K.; Wu, X.; Zhang, H.; Ren, Z. The physiological genetic effects of 1BL/1RS translocated chromosome in" stay green" wheat cultivar CN17. Can. J. Plant Sci. 2009, 89, 1-10. [CrossRef]

86. Mahalakshmi, V.; Bidinger, F.R. Evaluation of stay-green sorghum germplasm lines at ICRISAT. Crop Sci. 2002, 42, 965-974.

87. Howell, T.; Hale, I.; Jankuloski, L.; Bonafede, M.; Gilbert, M.; Dubcovsky, J. Mapping a region within the 1RS. 1BL translocation in common wheat affecting grain yield and canopy water status. Theor. Appl. Genet. 2014, 127, 2695-2709. [CrossRef]

88. Dhaliwal, A.; Mares, D.; Marshall, D. Effect of 1B/1R chromosome translocation on melling and quality characteristics of bread wheats. Cereal Chem. 1987, 64, 72-76.

89. Graybosch, R.; Peterson, C.; Hansen, L.; Mattern, P. Relationships between protein solubility characteristics, 1BL/1RS, high molecular weight glutenin composition, and end-use quality in winter wheat germ plasm. Cereal Chem. 1990, 67, 342-349.

90. Oak, M.D.; Tamhankar, S.A. 1BL/1RS translocation in durum wheat and its effect on end use quality traits. J. Plant Biochem. Biotechnol. 2017, 26, 91-96. [CrossRef]

91. Lundh, G.; MacRitchie, F. Size exclusion HPLC characterisation of gluten protein fractions varying in breadmaking potential. J. Cereal Sci. 1989, 10, 247-253. [CrossRef]

92. Finney, K.F. A ten-gram mixograph for determining and predicting functional properties of wheat flours. Bak. Dig. 1972, 46, $32-35,38-42,77$.

93. Lee, J.; Graybosch, R.; Peterson, C. Quality and biochemical effects of a IBL/IRS wheat-rye translocation in wheat. Theor. Appl. Genet. 1995, 90, 105-112. [CrossRef] [PubMed]

94. Dvořáček, V.; Bradová, J.; Stehno, Z. Effect of 1B/1R translocation on selected grain quality parameters in a set of doubled haploid wheat lines. Czech J. Genet. Plant Breed 2006, 42, 50-57. [CrossRef]

95. Blechl, A.; Beecher, B.; Vensel, W.; Tanaka, C.; Altenbach, S. RNA interference targeting rye secalins alters flour protein composition in a wheat variety carrying a 1BL. 1RS translocation. J. Cereal Sci. 2016, 68, 172-180. [CrossRef]

96. Barnes, W.C. Dough un-mixing time, and the sticky dough problem associated with Sr31 wheats. Euphytica 1990, 47, 49-55. [CrossRef]

97. Martin, D.; Stewart, B. Dough mixing properties of a wheat-rye derived cultivar. Euphytica 1986, 35, 225-232. [CrossRef]

98. Graybosch, R.; Peterson, C.; Hansen, L.; Worrall, D.; Shelton, D.; Lukaszewski, A. Comparative flour quality and protein characteristics of 1BL/1RS and 1AL/1RS wheat-rye translocation lines. J. Cereal Sci. 1993, 17, 95-106. [CrossRef]

99. Graybosch, R.A.; Peterson, C.J.; Shelton, D.R.; Baenziger, P.S. Genotypic and environmental modification of wheat flour protein composition in relation to end-use quality. Crop Sci. 1996, 36, 296-300. [CrossRef]

100. Graybosch, R.; Peterson, C.; Chung, O. Quality Effects of Rye (Secale cerealeL.) Chromosome Arm 1RL Transferred to Wheat (Triticum aestivumL.). J. Cereal Sci. 1999, 29, 211-216. [CrossRef]

101. Lukaszewski, A.J. Manipulation of the 1RS. 1BL translocation in wheat by induced homoeologous recombination. Crop Sci. 2000, 40, 216-225. [CrossRef]

102. Koebner, R.; Shepherd, K. Controlled introgression to wheat of genes from rye chromosome arm 1RS by induction of allosyndesis. Theor. Appl. Genet. 1986, 73, 197-208. [CrossRef]

103. Anugrahwati, D.R.; Shepherd, K.W.; Verlin, D.C.; Zhang, P.; Mirzaghaderi, G.; Walker, E.; Francki, M.G.; Dundas, I.S. Isolation of wheat-rye 1RS recombinants that break the linkage between the stem rust resistance gene SrR and secalin. Genome 2008, 51, 341-349. [CrossRef]

104. Sears, E.; Gustafson, J. Use of radiation to transfer alien chromosome segments to wheat. Crop Sci. 1993, 33, 897-901. [CrossRef]

105. Lei, M.-P.; Li, G.-R.; Zhou, L.; Li, C.-H.; Liu, C.; Yang, Z.-J. Identification of wheat-Secale africanum chromosome 2R afr introgression lines with novel disease resistance and agronomic characteristics. Euphytica 2013, 194, 197-205. [CrossRef] 
106. Singh, A.; Pallavi, J.; Gupta, P.; Prabhu, K. Identification of microsatellite markers linked to leaf rust resistance gene Lr25 in wheat. J. Appl. Genet. 2012, 53, 19-25. [CrossRef] [PubMed]

107. McIntosh, R.; Friebe, B.; Jiang, J.; Gill, B. Cytogenetical studies in wheat XVI. Chromosome location of a new gene for resistance to leaf rust in a Japanese wheat-rye translocation line. Euphytica 1995, 82, 141-147. [CrossRef]

108. Hysing, S.-C.; Hsam, S.L.; Singh, R.P.; Huerta-Espino, J.; Boyd, L.A.; Koebner, R.M.; Cambron, S.; Johnson, J.W.; Bland, D.E.; Liljeroth, E. Agronomic Performance and Multiple Disease Resistance in T2BS. 2RL Wheat-Rye Translocation Lines. Crop Sci. 2007, 47, 254-260. [CrossRef]

109. Rahmatov, M.; Rouse, M.N.; Nirmala, J.; Danilova, T.; Friebe, B.; Steffenson, B.J.; Johansson, E. A new 2DS. 2RL Robertsonian translocation transfers stem rust resistance gene Sr59 into wheat. Theor. Appl. Genet. 2016, 129, 1383-1392. [CrossRef] [PubMed]

110. Johansson, E.; Henriksson, T.; Prieto-Linde, M.L.; Andersson, S.; Ashraf, R.; Rahmatov, M. Diverse wheat-alien introgression lines as a basis for durable resistance and quality characteristics in bread wheat. Front. Plant Sci. 2020, 11, 1067. [CrossRef] [PubMed]

111. Zhuang, L.; Sun, L.; Li, A.; Chen, T.; Qi, Z. Identification and development of diagnostic markers for a powdery mildew resistance gene on chromosome 2R of Chinese rye cultivar Jingzhouheimai. Mol. Breed. 2011, 27, 455-465. [CrossRef]

112. An, D.G.; Li, L.H.; Li, J.M.; Li, H.J.; Zhu, Y.G. Introgression of resistance to powdery mildew conferred by chromosome 2 R by crossing wheat nullisomic 2D with rye. J. Integr. Plant Biol. 2006, 48, 838-847. [CrossRef]

113. Friebe, B.; Hatchett, J.; Sears, R.; Gill, B. Transfer of Hessian fly resistance from 'Chaupon'rye to hexaploid wheat via a 2BS/2RL wheat-rye chromosome translocation. Theor. Appl. Genet. 1990, 79, 385-389. [CrossRef]

114. Lahsaiezadeh, M.; Ting, I.; Waines, J. Drought resistance in Chinese Spring wheat/Imperial rye addition and substitution lines. In Proceedings of the Sixth International Wheat Genetics Symposium/edited by Sadao Sakamoto, Kyoto, Japan, 28 November-3 December 1983.

115. Ehdaie, B.; Hall, A.; Farquhar, G.; Nguyen, H.; Waines, J. Water-use efficiency and carbon isotope discrimination in wheat. Crop Sci. 1991, 31, 1282-1288. [CrossRef]

116. Ehdaie, B.; Whitkus, R.; Waines, J. Root biomass, water-use efficiency, and performance of wheat-rye translocations of chromosomes 1 and 2 in spring bread wheat 'Pavon'. Crop Sci. 2003, 43, 710-717. [CrossRef]

117. Fritz, A.; Sears, R. The effect of the Hamlet (2BS/2RL) translocation on yield components of hard red winter wheat. In Agronomy Abstracts; ASA: Madison, WI, USA, 1991; p. 94.

118. Nguyen, V.; Fleury, D.; Timmins, A.; Laga, H.; Hayden, M.; Mather, D.; Okada, T. Addition of rye chromosome 4R to wheat increases anther length and pollen grain number. Theor. Appl. Genet. 2015, 128, 953-964. [CrossRef]

119. Knackstedt, M.; Sears, R.; Rogers, D.; Lookhart, G. Effects of T2BS. 2RL Wheat-Rye Translocation on Breadmaking Quality in Wheat. Crop Sci. 1994, 34, 1066-1070. [CrossRef]

120. Boros, D.; Lukaszewski, A.; Aniol, A.; Ochodzki, P. Chromosome location of genes controlling the content of dietary fibre and arabinoxylans in rye. Euphytica 2002, 128, 1-8. [CrossRef]

121. Li, F.; Li, Y.; Cao, L.; Liu, P.; Geng, M.; Zhang, Q.; Qiu, L.; Sun, Q.; Xie, C. Simultaneous transfer of leaf rust and powdery mildew resistance genes from hexaploid triticale cultivar Sorento into bread wheat. Front. Plant Sci. 2018, 9, 85. [CrossRef] [PubMed]

122. Marais, G.; Marais, A. The derivation of compensating translocations involving homoeologous group 3 chromosomes of wheat and rye. Euphytica 1994, 79, 75-80. [CrossRef]

123. Miller, T. The homoeologous relationship between the chromosomes of rye and wheat. Current status. Can. J. Genet. Cytol. 1984, 26, 578-589. [CrossRef]

124. Rahmatov, M.; Rouse, M.N.; Steffenson, B.J.; Andersson, S.C.; Wanyera, R.; Pretorius, Z.A.; Houben, A.; Kumarse, N.; Bhavani, S.; Johansson, E. Sources of stem rust resistance in wheat-alien introgression lines. Plant Dis. 2016, 100, 1101-1109. [CrossRef]

125. Andersson, S.C.; Johansson, E.; Baum, M.; Rihawi, F.; El Bouhssini, M. New resistance sources to Russian wheat aphid (Diuraphis noxia) in Swedish wheat substitution and translocation lines with rye (Secale cereale) and Leymus mollis. Czech J. Genet. Plant Breed. 2015, 51, 162-165. [CrossRef]

126. Salvador-Moreno, N.; Ryan, P.; Holguín, I.; Delhaize, E.; Benito, C.; Gallego, F. Transcriptional profiling of wheat and wheat-rye addition lines to identify candidate genes for aluminum tolerance. Biol. Plant. 2018, 62, 741-749. [CrossRef]

127. Marais, G. An evaluation of three Sr27-carrying wheat $\times$ rye translocations. South Afr. J. Plant Soil 2001, 18, 135-136. [CrossRef]

128. Klocke, B. Virulenzstruktur und -Dynamik des Roggenbraunrostes (Puccinia recondita f. sp. secalis) in der Bundesrepublik Deutschland. Ph.D. Thesis, Martin Luther University, Halle-Wittenberg, Germany, 2004.

129. Roux, S.; Hackauf, B.; Ruge-Wehling, B.; Linz, A.; Wehling, P. Exploitation and comprehensive characterization of leaf-rust resistance in rye. Vortr. Pflanz. 2007, 71, 144-150.

130. Jurkowski, A.; Bujak, H. A search for 4 specific markers linked to Pm3 alleles for resistance to powdery mildew (Blumeria graminis) in rye (Secale cereale). Biol. Lett. 2019, 54, 37-45. [CrossRef]

131. Dhariwal, R.; Fedak, G.; Dion, Y.; Pozniak, C.; Laroche, A.; Eudes, F.; Randhawa, H.S. High density single nucleotide polymorphism (SNP) mapping and quantitative trait loci (QTL) analysis in a biparental spring triticale population localized major and minor effect Fusarium head blight resistance and associated traits QTL. Genes 2018, 9, 19. [CrossRef] [PubMed]

132. An, D.; Zheng, Q.; Zhou, Y.; Ma, P.; Lv, Z.; Li, L.; Li, B.; Luo, Q.; Xu, H.; Xu, Y. Molecular cytogenetic characterization of a new wheat-rye $4 \mathrm{R}$ chromosome translocation line resistant to powdery mildew. Chromosome Res. 2013, 21, 419-432. [CrossRef]

133. Fu, S.; Ren, Z.; Chen, X.; Yan, B.; Tan, F.; Fu, T.; Tang, Z. New wheat-rye 5DS-4RS. 4RL and 4RS-5DS. 5DL translocation lines with powdery mildew resistance. J. Plant Res. 2014, 127, 743-753. [CrossRef] 
134. An, D.; Ma, P.; Zheng, Q.; Fu, S.; Li, L.; Han, F.; Han, G.; Wang, J.; Xu, Y.; Jin, Y. Development and molecular cytogenetic identification of a new wheat-rye $4 \mathrm{R}$ chromosome disomic addition line with resistances to powdery mildew, stripe rust and sharp eyespot. Theor. Appl. Genet. 2019, 132, 257-272. [CrossRef]

135. Sidhu, M.; Satija, C.; Sharma, I. Screening of wheat-rye addition lines for Karnal bunt resistance. Crop Improv. India 2001, 28, 214-217.

136. Schneider, A.; Rakszegi, M.; Molnár-Láng, M.; Szakács, É. Production and cytomolecular identification of new wheat-perennial rye (Secale cereanum) disomic addition lines with yellow rust resistance (6R) and increased arabinoxylan and protein content (1R, 4R, 6R). Theor. Appl. Genet. 2016, 129, 1045-1059. [CrossRef] [PubMed]

137. Kattermann, G. Zur cytologie halmbehaarter stämme aus weizenroggenbastardierung. Der Züchter 1937, 9, 196-199. [CrossRef]

138. OMARA, J. The Substitution of a specific Secale-Cereale Chromosome for a Specific Triticum-Vulgare Chromosome. Genetics 1947, 32, 99-100.

139. Chumanova, E.; Efremova, T.; Trubacheeva, N.; Arbuzova, V.; Rosseeva, L. Chromosome composition of wheat-rye lines and the influence of rye chromosomes on disease resistance and agronomic traits. Russ. J. Genet. 2014, 50, 1169-1178. [CrossRef]

140. Rahmatov, M. Genetic Characterisation of Novel Resistance Alleles to Stem Rust and Stripe Rust in Wheat-Alien Introgression Lines. Acta Univ. Agric. Suec. 2016, 78, 1-76.

141. Xi, W.; Tang, Z.; Luo, J.; Fu, S. Physical Location of New Stripe Rust Resistance Gene (s) and PCR-Based Markers on Rye (Secale cereale L.) Chromosome 5 Using 5R Dissection Lines. Agronomy 2019, 9, 498. [CrossRef]

142. Li, G.; Gao, D.; La, S.; Wang, H.; Li, J.; He, W.; Yang, E.; Yang, Z. Characterization of wheat-Secale africanum chromosome 5R a derivatives carrying Secale specific genes for grain hardness. Planta 2016, 243, 1203-1212. [CrossRef]

143. Andersson, S.; Johansson, E.; Henriksson, T.; Rhamatov, M. Nya resistensgener för framtidens vete. LTV-Fak. Faktabl. 2016, 2, 1-4.

144. Bálint, A.; Kovács, G.; Börner, A.; Galiba, G.; Sutka, J. Substitution analysis of seedling stage copper tolerance in wheat. Acta Agron. Hung. 2003, 51, 397-404. [CrossRef]

145. Owuoche, J.; Briggs, K.; Taylor, G. The efficiency of copper use by 5A/5RL wheat-rye translocation lines and wheat (Triticum aestivum L.) cultivars. Plant Soil 1996, 180, 113-120. [CrossRef]

146. Schlegel, R.; Kynast, R.; Schwarzacher, T.; Römheld, V.; Walter, A. Mapping of genes for copper efficiency in rye and the relationship between copper and iron efficiency. Plant Soil 1993, 154, 61-65. [CrossRef]

147. Sibikeev, S.; Sibikeeva, Y.E.; Krupnov, V. Transmission of $5 \mathrm{R}$ chromosomes via gametes and its influence on spring bread wheat somatic embryoidogenesis in vitro. Russ. J. Genet. 2005, 41, 1366-1371. [CrossRef]

148. Du, H.; Tang, Z.; Duan, Q.; Tang, S.; Fu, S. Using the 6RLKu minichromosome of rye (Secale cereale L.) to create wheat-rye 6D/6RLKu small segment translocation lines with powdery mildew resistance. Int. J. Mol. Sci. 2018, 19, 3933. [CrossRef]

149. Li, J.; Dundas, I.; Dong, C.; Li, G.; Trethowan, R.; Yang, Z.; Hoxha, S.; Zhang, P. Identification and characterization of a new stripe rust resistance gene Yr83 on rye chromosome 6R in wheat. Theor. Appl. Genet. 2020, 133, 1095-1107. [CrossRef] [PubMed]

150. Friebe, B.; Heun, M.; Tuleen, N.; Zeller, F.; Gill, B. Cytogenetically monitored transfer of powdery mildew resistance from rye into wheat. Crop Sci. 1994, 34, 621-625. [CrossRef]

151. Hao, M.; Liu, M.; Luo, J.; Fan, C.; Yi, Y.; Zhang, L.; Yuan, Z.; Ning, S.; Zheng, Y.; Liu, D. Introgression of powdery mildew resistance gene Pm56 on rye chromosome arm 6RS into wheat. Front. Plant Sci. 2018, 9, 1040. [CrossRef] [PubMed]

152. An, D.; Zheng, Q.; Luo, Q.; Ma, P.; Zhang, H.; Li, L.; Han, F.; Xu, H.; Xu, Y.; Zhang, X. Molecular cytogenetic identification of a new wheat-rye 6R chromosome disomic addition line with powdery mildew resistance. PLoS ONE 2015, 10, e0134534. [CrossRef]

153. Cui, L.; Gao, X.; Wang, X.; Jian, H.; Tang, W.; Li, H.; Li, H. Characterization of interaction between wheat roots with different resistance and Heterodera filipjevi. Acta Agron. Sin. 2012, 38, 1009-1017. [CrossRef]

154. Ji-Lin, L.; Xiao-Ping, W.; Zhong, L.; Xiang-Ling, X. Study on homoeologous chromosome pairing and translocation induced by $5 \mathrm{~A} / 5 \mathrm{R} \times 6 \mathrm{~A} / 6 \mathrm{R}$ wheat-rye substitution lines. Acta Genet. Sin. 2006, 33, $244-250$.

155. Gruner, P.; Schmitt, A.-K.; Flath, K.; Schmiedchen, B.; Eifler, J.; Gordillo, A.; Schmidt, M.; Korzun, V.; Fromme, F.-J.; Siekmann, D. Mapping Stem Rust (Puccinia graminis f. sp. secalis) Resistance in Self-Fertile Winter Rye Populations. Front. Plant Sci. 2020, 11, 667. [CrossRef]

156. Nkongolo, K.; Quick, J.; Peairs, F.; Meyer, W. Gene location for Russian wheat aphid resistance of'Imperial'rye using wheat-rye addition lines. Cereal Res. Commun. 1990, 18, 307-313.

157. Farshadfar, E.; Mohammadi, R.; Farshadfar, M.; Dabiri, S. Relationships and repeatability of drought tolerance indices in wheat-rye disomic addition lines. Aust. J. Crop Sci. 2013, 7, 130.

158. Cakmak, I.; Derici, R.; Torun, B.; Tolay, I.; Braun, H.; Schlegel, R. Role of rye chromosomes in improvement of zinc efficiency in wheat and triticale. In Plant Nutrition for Sustainable Food Production and Environment; Springer: Berlin/Heidelberg, Germany, 1997; pp. 237-241.

159. FAO. WIEWS—World Information and Early Warning System on Plant Genetic Resources for Food and Agriculture; FAO: Rome, Italy, 2018.

160. Boczkowska, M.K.; Puchalski, J. SSR studies of genetic changes in relation to long-term storage and field regeneration of rye (Secale cereale) seeds. Seed Sci. Technol. 2012, 40, 63-72. [CrossRef]

161. Hawliczek, A.; Bolibok, L.; Tofil, K.; Borzęcka, E.; Jankowicz-Cieślak, J.; Gawroński, P.; Kral, A.; Till, B.J.; Bolibok-Bragoszewska, $\mathrm{H}$. Deep sampling and pooled amplicon sequencing reveals hidden genic variation in heterogeneous rye accessions. BMC Genom. 2020, 21, 1-16. [CrossRef] [PubMed] 
162. Bolibok-Bragoszewska, H.; Heller-Uszyńska, K.; Wenzl, P.; Uszyński, G.; Kilian, A.; Rakoczy-Trojanowska, M. DArT markers for the rye genome-genetic diversity and mapping. BMC Genom. 2009, 10, 578. [CrossRef] [PubMed]

163. Bolibok-Bragoszewska, H.; Targońska, M.; Bolibok, L.; Kilian, A.; Rakoczy-Trojanowska, M. Genome-wide characterization of genetic diversity and population structure in Secale. BMC Plant Biol. 2014, 14, 184. [CrossRef]

164. Targońska, M.; Bolibok-Bragoszewska, H.; Rakoczy-Trojanowska, M. Assessment of genetic diversity in Secale cereale based on SSR markers. Plant Mol. Biol. Report. 2016, 34, 37-51. [CrossRef]

165. Targońska-Karasek, M.; Bolibok-Bragoszewska, H.; Rakoczy-Trojanowska, M. DArTseq genotyping reveals high genetic diversity of polish rye inbred lines. Crop Sci. 2017, 57, 1906-1915. [CrossRef]

166. Targonska-Karasek, M.; Boczkowska, M.; Podyma, W.; Pasnik, M.; Niedzielski, M.; Rucinska, A.; Nowak-Zyczynska, Z.; RakoczyTrojanowska, M. Investigation of obsolete diversity of rye (Secale cereale L.) using multiplexed SSR fingerprinting and evaluation of agronomic traits. J. Appl. Genet. 2020, 61, 513-529. [CrossRef] [PubMed]

167. Khlestkina, E.; Shumny, V. Prospects for application of breakthrough technologies in breeding: The CRISPR/Cas9 system for plant genome editing. Russ. J. Genet. 2016, 52, 676-687. [CrossRef]

168. Taagen, E.; Bogdanove, A.J.; Sorrells, M.E. Counting on crossovers: Controlled recombination for plant breeding. Trends Plant Sci. 2020, 25, 455-465. [CrossRef]

169. Tam, S.M.; Hays, J.B.; Chetelat, R.T. Effects of suppressing the DNA mismatch repair system on homeologous recombination in tomato. Theor. Appl. Genet. 2011, 123, 1445-1458. [CrossRef]

170. de Maagd, R.A.; Loonen, A.; Chouaref, J.; Pelé, A.; Meijer-Dekens, F.; Fransz, P.; Bai, Y. CRISPR/Cas inactivation of RECQ 4 increases homeologous crossovers in an interspecific tomato hybrid. Plant Biotechnol. J. 2020, 18, 805-813. [CrossRef] [PubMed]

171. Rey, M.-D.; Martín, A.C.; Smedley, M.; Hayta, S.; Harwood, W.; Shaw, P.; Moore, G. Magnesium increases homoeologous crossover frequency during meiosis in ZIP4 (Ph1 Gene) mutant wheat-wild relative hybrids. Front. Plant Sci. 2018, 9, 509. [CrossRef] [PubMed] 